\title{
UJI AKTIVITAS ANTIBAKTERI JAMUR ENDOFIT AKAR BAKAU Avicennia marina TERHADAP BAKTERI Staphylococcus aureus dan Escherichia coli
}

\author{
Firdy Liwang, Robert Bara, Henoch Awaloei, Jane Wuisan \\ Bagian Farmakologi dan Terapi, Fakultas Kedokteran Universitas Sam Ratulangi Manado
}

\begin{abstract}
In this his study we used endophytic fungi isolated from the roots of mangrove Avicennia marina growing on tidal zone around Tasik Ria Minahasa, North Sulawesi. The fungi were isolated and then tested the antibacterial effect against Staphylococcus aureus and Escherichia coli. Potato Dextrose agar was used in order to isolate the target fungi. The fungi began to grow on the second day after inoculation. Differentiation and purification processes to isolate the fungus obtained by observing fungi mycelia. While, the antibacterial activity test was following agar diffusion assay by planting $10 \mathrm{~mm}$ diameter of fungal mycelium together with particular bacteria onto the combination media. Ciprofloxacin was used as a positive control. The results shows a visible bacterial inhibition zone around the growing fungi with a diameter between $18 \mathrm{~mm}$ to $20.4 \mathrm{~mm}$. Based on the results, it can be concluded that endophytic fungi isolated from the roots of mangrove Avicennia marina is able to inhibit the growth of S.aureus and E. coli.
\end{abstract}

Keyword: Avicennia marina, Antibacterial, endophytic fungi

\begin{abstract}
Abstrak: Penelitian ini menggunakan jamur endofit yang diisolasi dari akar tumbuhan bakau Avicennia marina yang tumbuh di perairan sekitar Tasik Ria Minahasa, Sulawesi Utara. Jamur endofit yang diisolasi kemudian diuji efek antibakteri terhadap bakteri Staphylococcus aureus dan Escherichia coli. Isolasi jamur endofit menggunakan media PDA (Potato Dextrose Agar). Jamur mulai tumbuh pada hari kedua setelah inokulasi. Proses pemurnian jamur diperoleh dengan mengisolasi jamur dengan membedakan miselia. Pengujian efek antibakteri mengikuti prosedur agar difusi dengan menanam miselium jamur sebesar $10 \mathrm{~mm}$ pada media kombinasi yang telah diolesi bakteri uji. Sebagai kontrol positif digunakan Ciprofloxacin. Hasil penelitian terlihat diameter zona hambat pertumbuhan bakteri yang terbentuk sebesar $18 \mathrm{~mm}$ hingga 20,4 mm. Berdasarkan hasil penelitian maka dapat disimpulkan jamur endofit yang diisolasi dari akar tumbuhan bakau Avicennia marina mampu menghambat pertumbuhan bakteri $S$. aureus dan bakteri E. coli.
\end{abstract}

Kata kunci: Avicennia marina, antibakteri, jamur endofit

Tumbuhan bakau (mangrove) memiliki banyak manfaat bagi kehidupan manusia, antara lain manfaat ekologi, pangan, dan obat. Tumbuhan bakau di Indonesia merupakan yang terbanyak di dunia, baik dari segi kuantitas area lebih dari $42.550 \mathrm{~km}^{2}$ maupun jumlah spesies lebih dari 45 spesies. Tumbuhan bakau secara turun temurun dimanfaatkan oleh masyarakat sebagai bahan berkhasiat obat. ${ }^{1}$ Beberapa ilmuan mengatakan bioaktivitas yang terdapat dalam bagian-bagian tumbuhan bakau tidak selalu berasal dari tumbuhan bakau itu sendiri, namun dapat berasal dari organisme lain yang hidup di bagian dari tumbuhan bakau dan organisme 
ini bisa mensintesis senyawa bioaktif yang dapat bersifat sebagai antibakteri. ${ }^{2}$

Penelitian untuk mencari sumber senyawa bioaktif terus dilakukan seiring dengan makin banyaknya penyakit-penyakit yang sebelumnya belum terdiagnosa dikarenakan alat-alat diagnostik yang kurang memadai. Terdapat beberapa sumber penghasil senyawa bioaktif antara lain tumbuhan, hewan, dan mikroba. ${ }^{3}$ Mikroba yang hidup di dalam jaringan tumbuhan disebut sebagai mikroba endofit. ${ }^{4}$ Mikroba endofit dalam jaringan tumbuhan, tumbuh bersama saling menguntungkan satu sama lain. Mikroba endofit akan memproduksi senyawa yang berfungsi untuk melindungi jaringan tumbuhan dari serangan mikroorganisme yang bersifat patogen. Jaringan tumbuhan akan menyediakan kebutuhan nutrisi bagi mikroba endofit agar dapat tetap hidup. Hubungan antara mikroba endofit dan jaringan tumbuhan ini dikenal sebagai hubungan simbiosis mutualisme. Mikroba endofit dapat berupa bakteri atau jamur. Saat ini banyak penelitian dilakukan pada jamur endofit, ini dikarenakan masyarakat ilmiah ingin membuktikan potensi senyawa bioaktif yang diproduksi oleh jamur endofit. ${ }^{5,6}$

Bakteri Staphylococcus aureus dan Escherichia coli merupakan penyebab tersering seseorang terkena diare di Indonesia. Kedua bakteri ini merupakan flora normal di saluran pencernaan tubuh manusia. Pada saat jumlah bakteri di saluran pencernaan meningkat dan bakteri keluar dari saluran pencernaan menuju ke daerah yang normalnya tidak ada kedua bakteri, contohnya bila bakteri Escherichia coli di dalam saluran pencernaan masuk ke dalam saluran kandung kemih dapat menyebabkan sistitis. Pada keadaan seperti ini maka kedua bakteri ini dapat bersifat patogen. Kedua bakteri ini dapat menyebabkan beberapa penyakit seperti infeksi saluran kemih, meningitis dan sepsis. ${ }^{7,8,9}$

\section{METODE PENELITIAN}

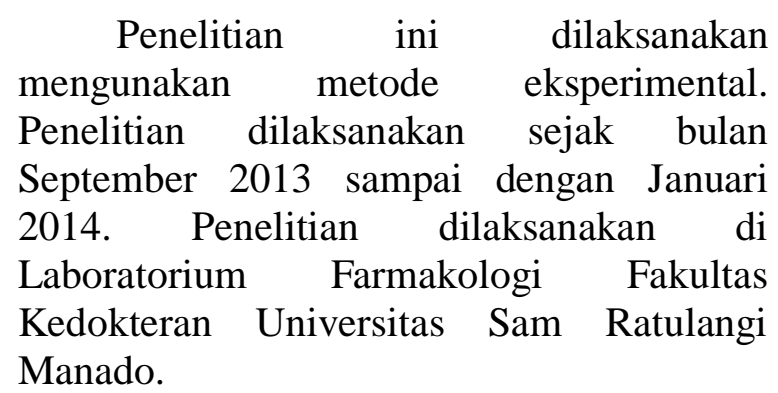

\section{Alat dan bahan}

Alat-alat yang digunakan dalam penelitian antara lain: cawan petri, tabung reaksi, pinset, kapas lidi steril, kertas saring, oven, inkubator, api bunsen, jarum ose, penggaris, sendok plastik, timbangan, tabung Erlenmeyer, kompor listrik, pisau kater, gunting, kamera, spidol, autoklaf, masker dan sarung tangan.

Bahan-bahan yang digunakan dalam penelitian antara lain: Akar tumbuhan bakau jenis Avicennia marina, bakteri Staphylococcus aureus, bakteri Escherichia coli, larutan McFarland, kapas steril, PDA (Potato Dextrose Agar), cairan dextrose 5\%, alkohol 70\%, kloramfenikol, siprofloksasin, nutrient agar (NA), akuades.

\section{Isolasi jamur endofit}

Alat-alat yang digunakan disterilkan dalam oven pada suhu $170^{\circ} \mathrm{C}$ selama \pm 1 jam. Media disterilkan dalam autoclave pada suhu $121^{\circ} \mathrm{C}$ selama 15 menit. Akar tumbuhan bakau Avicennia marina diambil dari pesisir pantai tasik ria Minahasa, Sulawesi Utara. Akar bakau dipotong sepanjang $5 \mathrm{~cm}$ dan direndam dalam larutan alkohol 70\% selama 30 detik. Akar bakau yang telah direndam diambil dan dipotong bagian tengah sepanjang $1 \mathrm{~cm}$. Potongan 
akar bakau ditanam pada media PDA (Potato Dextrose Agar) ditambahkan Kloramfenikol 0,2 g/ml didalam cawan petri. Tutup cawan petri dan simpan pada suhu ruangan selama 2x24 jam untuk menumbuhkan jamur. Pada hari kedua akan terlihat pertumbuhan jamur di sekitar akar bakau. Setiap akar bakau yang ditanam dapat tumbuh beberapa koloni jamur endofit yang berbeda.

\section{Pemurnian jamur endofit}

Koloni jamur endofit yang sudah tumbuh diambil dan ditumbuhkan di media lain agar mendapatkan satu jenis jamur endofit yang murni. Setiap koloni jamur endofit yang secara morfologi berbeda akan dilakukan pemurnian. Pemurnian ini bertujuan untuk memisahkan koloni jamur endofit dengan morfologi yang berbeda untuk dijadikan isolat tersendiri. Simpan pada suhu ruangan selama 2 x 24 jam.

\section{Penyiapan bakteri uji}

Nutrien agar ditimbang sebanyak 23 gram dan dilarutkan dalam 1 liter akuades. $\mathrm{pH}$ diukur hingga mencapai 6,8. Media disterilkan dan dituang kedalam tabung reaksi sebanyak $7 \mathrm{ml}$ dan dibiarkan mengeras dengan kemiringan $15^{\circ}$. Brain Heart Infusion (BHI) ditimbang sebanyak 37 g kemudian dilarutkan dalam $1 \mathrm{~L}$ akuades. Media disterilkan dan dituang kedalam tabung reaksi sebanyak $5 \mathrm{ml}$ untuk selanjutnya digunakan sebagai media suspensi bakteri. Bakteri yang dikultur pada agar miring diambil dengan menggunakan kawat ose steril dan dimasukkan ke dalam media BHI. Kekeruhan larutan bakteri distandarisasi dengan Larutan kekeruhan
Mc. Farland. Suspensi bakteri kemudian digoreskan dengan menggunakan lidi kapas steril di atas permukaan media kombinasi. Jamur endofit yang telah tumbuh pada media PDA (Potato Dextrose Agar) kemudian dipotong berbentuk bulat dan diletakkan pada media kombinasi PDA (Potato Dextrose Agar) dan NA (Nutrient Agar) yang telah digoresi oleh bakteri uji.

\section{Uji daya hambat jamur endofit dan pengukuran zona hambat}

Penanaman jamur dilakukan 5 kali pengulangan pada 1 cawan petri dengan jarak yang sama. Ciprofloxacin dilarutkan sebanyak $2 \mathrm{mg} / \mathrm{ml}$. Kertas saring yang berbentuk bulat kecil dicelup ke dalam larutan antibiotik kemudian diletakkan ditengah-tengah dari media, selanjutnya diinkubasi pada suhu ruangan.

Zona hambat adalah daerah jernih yang terbentuk dimana daerah tersebut tidak terdapat pertumbuhan bakteri. Zona hambat dari masing-masing sampel jamur endofit diamati setelah 1 x 24 jam. Pengukuran zona hambat dilakukan dengan menggunakan penggaris dengan cara membalik cawan petri dan mengukur diameter daerah jernih.

\section{HASIL}

Jamur endofit yang tumbuh dari potongan akar tumbuhan bakau Avicennia marina diperoleh jamur endofit berwarna hitam dan jamur endofit berwarna putih. Diameter zona hambat yang terbentuk dari kedua jamur endofit dapat dilihat pada gambar 1 , sedangkan pengukuran diameter zona hambat dapat dilihat pada Tabel 1 dan 2 berikut ini. 


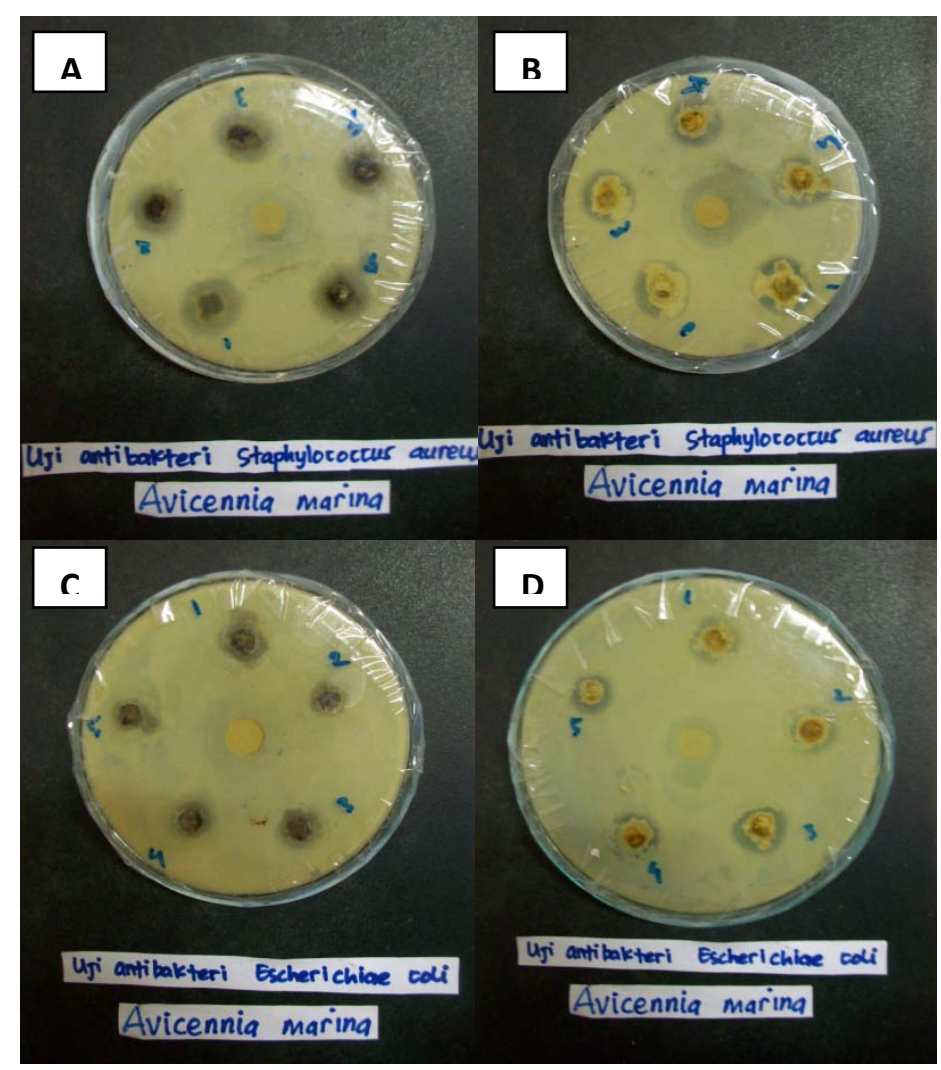

Gambar 1. A. Diameter zona hambat jamur endofit berwarna hitam terhadap bakteri $S$. aureus, B. Diameter zona hambat jamur endofit berwarna putih terhadap bakteri S. aureus, C. Diameter zona hambat jamur endofit berwarna hitam terhadap bakteri E. coli, D. Diameter zona hambat jamur endofit berwarna putih terhadap bakteri E. coli

Tabel 1: Hasil uji efek antibakteri jamur endofit terhadap pertumbuhan bakteri Staphylococcus aureus

\begin{tabular}{ccccc}
\hline \multirow{2}{*}{ Sampel } & \multirow{2}{*}{ Diameter jamur $(\mathrm{mm})$} & \multicolumn{2}{c}{ Diameter zona hambat $(\mathrm{mm})$} & \multirow{2}{*}{ Kontrol $(+)$} \\
\cline { 3 - 4 } & & Jamur hitam & Jamur putih & \\
\hline 1. & 10 & 20 & 20 & 19 \\
2. & 10 & 18 & 21 & 19 \\
3. & 10 & 20 & 20 & 19 \\
4. & 10 & 19 & 19 & 19 \\
5. & 10 & 20 & 22 & 19 \\
& Rata-rata & 19,4 & 20,4 & 19 \\
\hline
\end{tabular}


Tabel 2: Hasil uji efek antibakteri jamur endofit terhadap pertumbuhan bakteri Escherichia coli

\begin{tabular}{ccccc}
\hline \multirow{2}{*}{ Sampel } & \multirow{2}{*}{ Diameter jamur $(\mathrm{mm})$} & \multicolumn{2}{c}{ Diameter zona hambat $(\mathrm{mm})$} & \multirow{2}{*}{ Kontrol(+) } \\
\cline { 3 - 4 } & & Jamur hitam & Jamur putih & \\
\hline 1. & 10 & 21 & 18 & 19,5 \\
2. & 10 & 21 & 18 & 19,5 \\
3. & 10 & 20 & 19 & 19,5 \\
4. & 10 & 20 & 19 & 19,5 \\
5. & 10 & 20 & 16 & 19,5 \\
& Rata-rata & 20,4 & 18 & 19,5 \\
\hline
\end{tabular}

\section{PEMBAHASAN}

Pada penelitian ini diperoleh jamur endofit berwarna hitam dan jamur endofit berwarna putih. Jamur endofit berwarna hitam dan putih diisolasi dari akar tumbuhan bakau Avicennia marina. Jamur endofit yang diisolasi dilakukan pengujian daya hambat pertumbuhan bakteri uji yaitu bakteri Staphylococcus aureus dan bakteri Escherichia coli. Bakteri Staphylococcus aureus sebagai bakteri gram positif dan bakteri Escherichia coli sebagai bakteri gram negatif.

Hasil pengujian jamur endofit akar tumbuhan bakau Avicennia marina terdapat daya hambat pertumbuhan bakteri. Pada pengukuran diameter zona hambat didapatkan rata-rata daya hambat jamur endofit berwarna hitam lebih besar dari pada jamur endofit berwarna putih. Daya hambat pertumbuhan bakteri jamur endofit berwarna hitam lebih besar dari pada jamur endofit berwarna putih diduga terjadi karena konsentrasi tumbuh pada jamur endofit berwarna hitam lebih baik dari pada jamur endofit berwarna putih. Jamur endofit berwarna hitam memiliki daya hambat pertumbuhan bakteri yang hampir sama dengan kontrol positif. Kontrol positif menghambat pertumbuhan bakteri dengan mekanisme menghambat terbentuknya DNA girase yang dibutuhkan bakteri untuk bereplikasi. Kontrol positif yang digunakan yaitu siprofloksasin. ${ }^{10}$ Pada jamur endofit berwarna hitam belum diketahui mekanisme penghambatan bakteri. Perbandingan daya hambat pertumbuhan bakteri antara jamur endofit berwarna putih dengan kontrol positif juga tidak memiliki perbedaan yang signifikan.

Jamur endofit yang berwarna hitam maupun yang berwarna putih diduga terdapat senyawa antibakteri, dugaan ini diperkuat dengan ditemukannya senyawa cytocidal, chlovalicin, isocoumarins, dan senyawa taxol yang berfungsi sebagai antibiotik, anti inflamasi, anti alergi dan anti kanker. Senyawa cytocidal dan chlovalicin di temukan dalam jamur endofit yang diisolasi dari tumbuhan bakau Kandelia candel. Senyawa isocoumarins di temukan dalam jamur endofit yang diisolasi dari daun muda tumbuhan bakau Avicennia marina yang ditemukan di Pearl River Estuary, Cina selatan dan senyawa taxol terkandung dalam jamur endofit yang di temukan di Filbert. $^{11,12,13}$ Senyawa-senyawa yang dihasilkan oleh tumbuhan bakau kemungkinan merupakan mekanisme perlindungan diri terhadap mikroorganisme yang bersifat patogen seperti bakteri yang 
menyerang di lingkungan sekitarnya. Senyawa yang dihasilkan untuk mekanisme perlindungan diri ini lah yang bisa dimanfaatkan oleh manusia.

Berdasarkan hasil penelitian terlihat kontrol positif mampu menghambat pertumbuhan bakteri Escherichia coli lebih baik dari pada menghambat pertumbuhan bakteri Staphylococcus aureus. Kemampuan kontrol positif ini dikarenakan kontrol positif lebih sensitif terhadap bakteri Escherichia coli dari pada bakteri Staphylococcus aureus. ${ }^{14}$

\section{KESIMPULAN DAN SARAN}

\section{kesimpulan}

Berdasarkan hasil pengujian jamur endofit yang diisolasi dari tumbuhan bakau Avicennia marina terhadap bakteri Staphylococcus aureus dan bakteri Escherichia coli, maka disimpulkan bahwa jamur endofit yang diisolasi dari tumbuhan bakau Avicennia marina mampu menghambat pertumbuhan bakteri Staphylococcus aureus dan bakteri Escherichia coli.

\section{Saran}

1. Perlu dilakukan penelitian lebih lanjut untuk mengidentifikasi senyawa yang berkhasiat anti pertumbuhan bakteri pada jamur endofit yang diisolasi dari tumbuhan bakau Avicennia marina.

2. Perlu dilakukan penelitian lebih lanjut untuk mengetahui mekanisme kerja anti pertumbuhan bakteri pada jamur endofit yang diisolasi dari tumbuhan bakau Avicennia marina.

3. Perlu dilakukan penelitian lebih lanjut tentang daya hambat pertumbuhan pada mikroorganisme lainnya.

4. Perlu penelitian lebih lanjut kemampuan daya hambat pertumbuhan bakteri dengan mengunakaan jamur endofit yang diisolasi dari bagian lain tumbuhan bakau Avicennia marina.

\section{DAFTAR PUSTAKA}

1. Purnobasuki H. Potensi Mangrove Sebagai Tanaman Obat. Biota. 2004;IX:125-126

2. Prihanto AA. Perbandingan Aktivitas Antibakteri Penicillium notatum ATCC 28089 Dengan Penicillium sp. R1M yang Diisolasi dari Mangrove Sonneratia caseolari. Fakultas Perikanan dan Ilmu Kelautan Universitas Brawijaya

3. Prihatiningtias W, Wahyuningsih MSH. Prospek Mikroba Endofit Sebagai Sumber Senyawa Bioaktif. Universitas Gadjah Mada

4. Kumala S, Agustina E, Wahyudi P. Uji Aktivitas Antimikroba Metabolit Sekunder Kapang Endofit Tanaman Trengguli (Cassia fistula L). Jurnal Bahan Alam Indonesia ISSN 14122855. 2007;6:46

5. Sinaga E, Noverita, Fitria D. Daya antibakteri jamur endofit yang diisolasi dari daun dan rimpang lengkuas (Alpinia galangal Sw.). Jurnal Farmasi Indonesia. 2009;4:161-162

6. Strobel G, Daisy B. Bioprospecting For Microbial Endophytes and Their Natural Products. Microbiology and Molecular Biology Reviews. 2003;67:492

7. Kusuma SAF. Staphylococcus aureus [makalah]. Jatinangor: Fakultas Farmasi Universitas Padjadjaran; 2009.

8. Kusuma SAF. Escherichia coli [makalah]. Jatinangor: Fakultas Farmasi Universitas padjadjaran; 2010.

9. Melliawati R. Escherichia coli Dalam Kehidupan Manusia. BioTrends. 2009;4:10

10. Zakiah N. Uji "Toksisitas Perkembangan” siprofloksasin dan studi histologi terhadap mencit putih. Penelitian 
11. Pan JH, Jones EBG, She ZG, Pang JY, and Lin YC. Bioactive compounds from fungi in the south china sea. Botanica marina. 2008;51:183

12. Wen L, Cai X, Xu F, She Z, Chan WL, Vrijmoed LLP, Jones EBG and Lin Y. Three metabolites from the mangrove endophytic fungus sporothrix sp. (\#4335) from the south china sea. The journal of organic chemistry. 2009;74:1094

13. Strobel GA. Microbial gifts from rain forests. Can. J. Plant Pathol. 2002;24:15

14. Utami ER. Antibiotika, resistensi, dan rasionalitas terapi. Sainstis. 2012. 1. 1. $125-127$ 